\title{
Bioaccumulation of Heavy Metals and Optimization of Lipase Production by Lysinibacillus sphaericus Strain ODE16_EKITI Isolated from Domestic Oil-Rich Wastewater
}

\author{
B.I. Aderiye*, A.A. Adebayo and Bello, Mustapha \\ Department of Microbiology, Faculty of Science, Ekiti State University, Ado-Ekiti, Nigeria \\ *Corresponding author
}

\section{A B S T R A C T}

\begin{tabular}{|l|}
\hline Key w or d s \\
$\begin{array}{l}\text { Bioaccumulation, } \\
\text { Lysinibacillus } \\
\text { sphaericus strain } \\
\text { ODE16_EKITI, } \\
\text { lipase production, } \\
\text { remediation, } \\
\text { Optimization. }\end{array}$ \\
\hline Article Info \\
\hline $\begin{array}{l}\text { Accepted: } \\
\text { 20 June 2017 } \\
\text { Available Online: } \\
\text { 10 August } 2017\end{array}$ \\
\hline \hline
\end{tabular}

In a bid to remediate the menace caused by the presence of lipids in many biological wastewater treatment systems, various researchers have focused on a way to explore lipase production by different microorganisms for this purpose. Some cultural parameters were hence optimized while their influences on the production of lipase by Lysinibacillus sphaericus strain ODE16_EKITI in an oil-rich wastewater were enumerated using standard laboratory techniques. Inorganic content of the sample and lipase production were estimated using atomic absorption spectrophotometry and lipase colorimetry respectively. Magnesium $(\mathrm{Mg})$ constituted the highest metal concentration of $54.5 \mathrm{mg} / \mathrm{L}$ while least concentration of calcium $(\mathrm{Ca})(13.4 \mathrm{mg} / \mathrm{L})$ in the wastewater sample and iron $(\mathrm{Fe})$ as the only heavy metal detected in high concentration $(31.6 \mathrm{mg} / \mathrm{mL})$. No significant difference in the accumulation potential of the consortium that took up $77.85 \%$ of phosphate and that of the organism, which accumulated $77.38 \%$ of phosphates in the sample. The maximum lipase activity $(5.111 \mathrm{mMol})$ was recorded after 5 days' incubation, with the production rate of $0.78 \mathrm{mM} / \mathrm{min}$ daily and the microbial growth rate of $0.292 \mathrm{mg} /$ day. The organism had the highest growth (OD 0.298 ) and lipase production $(6.667 \mathrm{mMol})$ with oil concentration of $2.5 \mathrm{ml} / \mathrm{L}$ at optimum temperature of $30^{\circ} \mathrm{C}$. L. sphaericus also showed the highest growth (with OD 0.301) and lipase production of $6.67 \mathrm{mMol}$ in the presence of magnesium ion $\left(\mathrm{Mg}^{2+}\right)$. The present work has offered us the chance to explore a lipolytic bacterium, Lysinibacillus sphaericus strain ODE16_EKITI that can produce lipase ranging between $5.1 \mathrm{mMol}$ to $6 \mathrm{mMol}$ at $30^{\circ} \mathrm{C}$ and $2.5 \%$ palm oil concentration after 5 days. This organism also showed potentials for bioaccumulation of some heavy metals. L. sphaericus strain ODE16_EKITI is thereby presented as a promising tool for biotechnological exploitation in remediation of domestic oil-rich wastewater.

\section{Introduction}

Globally, one of the major environmental pollutions detrimental to the ecosystem, including human communities, is a consequence of either deliberate and sometimes regulated (e.g. Industrial emissions) or accidental and mostly unavoidable (e.g. chemical spills) release of quantities of oil-rich effluents, resulting from human activities. These pollutants are majorly from industries (i.e. food, chemical, pharmaceutical, cosmetic, leather and detergent), restaurants, slaughter house, and households (Shukia and Desai, 2016). Apparently, all anthropogenic activities end 
with wastewater, although cannot be quantified but has been estimated that, globally, about $80 \%$ of wastewater from human settlements and industrial sources is discharged to the environment without treatment (UNEP and UN-Habitat, 2010). Wastewater effluents from restaurants have attracted interest because of the high concentration $(>100 \mathrm{mg} / \mathrm{L})$ of stable organic compounds; lipids (fats and oils), important component of vegetable oil (Prasad and Majunath, 2010; Odeyemi et al., 2013a), that cause major problems in wastewater treatment process, by forming layers on water surface and decrease oxygen transfer rate in the aerobic process (Facchin et al., 2013).

Biological treatment comprising of bioremediation and manipulation of microbes, has however been and remains the most efficient, cost effective, ecofriendly and easy approach to stop this menace. In view of this, several attempts have been made to isolate lipase-producing bacteria (Dharmusthii and Luchai, 1999; Kambovrova et al., 2003; Trichel et al., 2010; Facchin et al., 2013; Odeyemi et al., 2013a; 2014; Coronado et al., 2015) and fungi (Maier et al., 2003; Odeyemi et al., 2013b). In recent times, the interest of researchers in microbial lipase is heightened, not only for its biodegradative and bioremediating capabilities, but also its industrial applications including in, production of surfactant (Bora and Kalita, 2007), cheese ripening and flavour enhancement (Mukesh Kumar et al., 2012), and production of chiral drugs (Reddy and Pallavi, 2012). Furthermore, microbial lipases which includes important biotechnologically valuable enzymes degrade these wastes, mainly because of their stability, selectivity, broad substrate specificity, versatile properties for application and ease of mass production (Shukia and Desai, 2016). The search for new lipase with different characteristics becomes so eminent in recent time, because their specificity is still a limiting factor, as different properties could be required for a particular application. More so, the production of lipases by a microorganism is influenced by several extrinsic and intrinsic factors (Pallavi et al., 2014). In a previous study by Odeyemi et al., (2014), Lysinibacillus sphaericus strain ODE16_EKITI isolated from a vegetable oilrich wastewater was reported as an efficient lipase producer. Efforts were therefore made in this present research to optimize and enumerate the influence of some cultural parameters for maximum production of lipase by the bacteria, Lysinibacillus sphaericus strain ODE16_EKITI.

\section{Materials and Methods}

\section{Source and collection of wastewater sample}

Wastewater sample was collected aseptically from different sampling points including wash-hand basin, dish washing and dish rinsing bowls at Falegan restaurant situated along the Ekiti State Secretariat road, AdoEkiti, Nigeria. The wastewater contained food remnants and cleaning soap solution. The sample was collected using sterile $250 \mathrm{~mL}$ Erlenmeyer bottle, transported in ice ($5^{\circ} \mathrm{C} \pm 1^{\circ} \mathrm{C}$ ) to the Microbiology laboratory of the Ekiti State University, Ado-Ekiti until when needed.

\section{Preparation of wastewater sample for mineral analysis}

About $5 \mathrm{ml}$ of concentrated $\mathrm{HCl}$ was added to $250 \mathrm{~mL}$ of wastewater sample and evaporated to $25 \mathrm{ml}$. The concentrate was transferred to a $250 \mathrm{~mL}$ Erlenmeyer flask and made up to the $50 \mathrm{~mL}$ with distilled de-ionized water (APHA, 1998; Odeyemi et al., 2013b).

\section{Mineral analysis of wastewater sample}

Mineral analysis of wastewater sample was carried out in accordance with AOAC (2006) 
description; heavy metals such as lead $(\mathrm{Pb})$, copper $(\mathrm{Cu})$, manganese $(\mathrm{Mn})$, nickel $(\mathrm{Ni})$, iron $(\mathrm{Fe})$ and $\mathrm{Zinc}(\mathrm{Zn})$ were analysed using Atomic Absorption Spectrophotometer (AAS) (PYE Unicam Sp 9, Cambridge, UK), while potassium, sodium, magnesium and calcium were analysed using the Flame Photometer (BUCK 2010 VGP).

The amount of active ingredients (silica, soda ash, surfactant and phosphate) in the wastewater was determined with a Spectronic 20 colorimeter (Gallenkamp, UK) as described by AOAC (1990).

\section{Source of bacterial isolate}

The bacterial isolate, Lysinibacillus sphaericus strain ODE16_EKITI used in this study has been described and molecularly characterized by Odeyemi et al., (2014) and kept on an agar slant in the Department of Microbiology Laboratory, Ekiti State University, Ado Ekiti, Nigeria.

\section{Preparation of inoculum}

Bacterial culture was streaked on to freshly prepared nutrient agar (Lab M, UK) plate, a distinct colony was picked and inoculated into agar slant, and was incubated for 24hours. Slanted culture was stocked at $4^{\circ} \mathrm{C}$. A loopful of cells from a freshly grown slant was transferred into a $250 \mathrm{~mL}$ Erlenmeyer flask containing $50 \mathrm{~mL}$ of minimal media (without agar); $1.5 \% \quad \mathrm{~K}_{2} \mathrm{HSO}_{4}, 0.05 \% \quad \mathrm{MgSO}_{4}, 1.0 \%$ $\left(\mathrm{NH}_{4}\right)_{2} \mathrm{SO}_{4}, 0.2 \% \mathrm{CaCl}_{2}, 0.2 \% \mathrm{FeSO}_{4}$ in 1 litre of distilled water and incubated at $30^{\circ} \mathrm{C}$ in a shaking incubator at $180 \mathrm{rpm}$ for $24 \mathrm{~h}$ (Gupta et al., 2004).

Lipase assay medium $(0.2 \%$ v/v palm oil, $1.5 \% \quad \mathrm{~K}_{2} \mathrm{HSO}_{4}, \quad 0.05 \% \quad \mathrm{MgSO}_{4}, \quad 1.0 \%$ $\left(\mathrm{NH}_{4}\right)_{2} \mathrm{SO}_{4}, 0.2 \% \quad \mathrm{CaCl}_{2}, 0.2 \% \quad \mathrm{FeSO}_{4}$ and $0.5 \%$ yeast extract) at $\mathrm{pH} 7$ was used for enzyme assay.

\section{Estimation of microbial growth}

Aliquots of the culture suspension were withdrawn at specific conditions and the cells were harvested after centrifugation (10,000rpm at $4^{\circ} \mathrm{C}$ for $\left.30 \mathrm{mins}\right)$. The cells were macerated with $1 \mathrm{~mL}$ normal saline and the absorbance was measured at $600 \mathrm{~nm}$ with Atomic Absorption Spectrophotometer (PYE UnicamSp 9, Cambridge, UK) to determine the optimum growth (Gupta et al., 2004).

\section{Estimation of lipase activity}

Crude enzyme $(1 \mathrm{~mL})$ obtained as cell free supernatant after centrifugation at $10,000 \mathrm{~g}$ for $30 \mathrm{~min}$ (usually stored at $4^{\circ} \mathrm{C}$ until needed) was assayed for lipase activity using colorimetric method described by Lotrakul and Dharmsthiti (1997).

Lipase activity was determined based on the cleavage of $\mathrm{p}$-nitrophenylpalmitate ( $\mathrm{p}-\mathrm{NPP}$ ) at $\mathrm{pH}$ 8.0. The reaction mixture contained $180 \mu \mathrm{L}$ of solution A (0:062 $\mathrm{g}$ of $\mathrm{p}$-NPP in 10 $\mathrm{mL}$ of 2-propanol, sonicated for $2 \mathrm{~min}$ before use), $1620 \mu \mathrm{L}$ of solution B (0.4\% triton X100 and $0.1 \%$ Arabic gum in 50 mMTris$\mathrm{HCl}, \mathrm{pH} 8.0$ ) and $200 \mu \mathrm{L}$ of properly diluted enzyme sample. Optical density of the solution was measured at $410 \mathrm{~nm}$ wavelength after incubation for $15 \mathrm{~min}$ at $37^{\circ} \mathrm{C}$. One unit of lipase activity was defined as the amount of lipase releasing $1 \mu \mathrm{mol}$ of p-nitrophenol (pNP) per minute by $1 \mathrm{~mL}$ of enzyme (Cho et al., 2000; Shukia and Desai, 2016).

\section{Optimization of conditions for microbial growth and lipase production}

Various cultural parameters affecting enzyme production were independently optimized. In all cases, $1 \mathrm{ml}$ of $1.86 \times 10^{6} \mathrm{CFU} / \mathrm{mL}$ bacterial suspension was added to the medium (Gupta et al., 2004). 


\section{Incubation periods}

Microbial load and lipase production were estimated for 6days at 24hours interval of incubation.

\section{Oil concentrations}

Palm oil was inculcated into the inoculated minimal medium at different concentrations ranging from $0.50 \%$ to $4.0 \%(\mathrm{v} / \mathrm{v})$ and the microbial growth and lipase production were estimated.

\section{Temperatures}

The optimum temperature for optimal growth and lipase activity was determined by incubating the assay solution at different temperatures between $20^{\circ} \mathrm{C}$ and $50^{\circ} \mathrm{C}$ with readings taken at $10^{\circ} \mathrm{C}$ intervals for 24 hours.

\section{Metals}

Effect of metals on the growth and lipase production by $L$. sphaericus strain ODE16_EKITI was examined. $1 \mathrm{mg}$ of metals such as sodium (Na), potassium $(\mathrm{K})$, magnesium $(\mathrm{Mg})$ and iron $(\mathrm{Fe})$ were inculcated into the assay suspension and incubated for 1 hour at $30^{\circ} \mathrm{C}$ before spectrophotometric and colorimetric assay (Mukesh Kumar et al., 2012).

\section{Bioaccumulation of inorganic compounds}

Lysinibacillus sphaericus strain ODE16_EKITI was used separately in the sterile medium and in combination with indigenous organisms in the wastewater to test their accumulation abilities under nonagitation condition (Ray, 2009). By heating $500 \mathrm{ml}$ of wastewater sample (in sterile round bottom flask) in a water bath (Model CS200) at $47^{\circ} \mathrm{C}$, fats and oils in the sample were homogenised and uniformly distributed
(Huges and Christy, 2003). The experiment was set in three categories; control, which was sterilized and not inoculated; sample A, which was sterilized and inoculated with $L$. sphaericus; and sample B, which was nonsterile and inoculated. Sterilization of control and sample A was done using UV radiation with $60 \mathrm{~Hz}$ (Model FG-Y15W).

Inoculated samples were incubated at $37^{\circ} \mathrm{C}$ for 7days un-agitated after which were centrifuged at $10,000 \mathrm{rpm}$ for $30 \mathrm{~min}$. The supernatant contained the inorganic compounds that were not accumulated while the residue contained the organisms with accumulated inorganic compounds. The organisms (in the residue) were then lysed immediately using sodium dodecyl sulphate (SDS) so that the contents that have been accumulated over the period will be released. The mineral content of both the supernatant and the residue was analysed (Sulaimon et al., 2014).

\section{Results and Discussion}

\section{Inorganic components of wastewater}

Inorganic components, which included metal/heavy metal contents and active ingredient of vegetable oil-rich wastewater obtained from Falegan restaurant, Ado-Ekiti, were estimated and depicted in Table 1. Magnesium $(\mathrm{Mg})$ constituted the highest metal concentration of $54.5 \mathrm{mg} / \mathrm{L} n$ the wastewater ample. Among the heavy metals, only iron $(\mathrm{Fe})$ was significantly high with $31.6 \mathrm{mg} / \mathrm{L}$ concentration, and a trace amount of copper $(\mathrm{Cu})$ with $0.08 \mathrm{mg} / \mathrm{L}$. Heavy metals such as nickel and lead were not detected in any of the samples. The concentrations of each active ingredient in the sample was also presented in Table 1: phosphates $\left(\mathrm{PO}_{4}\right)$ $6.41 \mathrm{mg} / \mathrm{L}$, sulphates $\left(\mathrm{SO}_{4}\right) 4.67 \mathrm{mg} / \mathrm{L}$, silica $1.65 \mathrm{mg} / \mathrm{L}$, soda ash $0.82 \mathrm{mg} / \mathrm{L}$ and surfactants $0.02 \mathrm{mg} / \mathrm{L}$. 
Bioaccumulation of inorganic components of oil-rich wastewater sample by $L$. sphaericus

The trend of accumulation of inorganic components of oil rich wastewater by Lysinibacillus sphaericus strain ODE16_EKITI is shown in Figure 1.

About $98 \%$ (97.8\%) of total calcium (Ca) was accumulated L. sphaericus, while the consortium of microbes absorbed $100 \%$ of the calcium. Forty-four point six percent of iron in the wastewater sample was accumulated by the isolate. It is therefore obvious that calcium and potassium were very important for the growth of Lysinibacillus sphaericus was able to accumulated iron.

There was no significant difference in the accumulation potential of the consortium, which took up $4.99 \mathrm{mg} / \mathrm{L}$ of phosphate and that of the organism, which accumulated $4.96 \mathrm{mg} / \mathrm{L}$ of phosphates present in the sample. This showed that the test organism is the major bioaccumulator of phosphate, while it showed a $0 \%$ affinity for sulphate as there was no trace of sulphate in their cell.

\section{Effect of Incubation Time on Growth and Lipase Production}

The effect of incubation time on growth of Lysinibacillus sphaericus strain ODE16_EKITI and its lipase production was determined for a period of six days (Figure 2). It was observed that the highest growth of the isolate (with OD 1.443) was obtained on the fourth day which gradually reduced by $21 \%$ on the sixth day (with OD 1.143). Lipase production by $L$. sphaericus increased steadily with growth for the first three days with $2.977 \mathrm{mMol}$ of lipase, which reduced to $2.866 \mathrm{mMol}$ on the fourth day, and finally recorded the highest production of $5.111 \mathrm{mMol}$ on the sixth day.

\section{Effect of Oil Concentration on Growth and} Lipase Production

The lipase production was inversely proportional to the growth of Lysinibacillus sphaericus strain ODE16_EKITI as shown in Figure 3. At oil concentration of $0.5 \mathrm{ml} / \mathrm{L}$, the growth indicated by the optical density was 0.205 while the lipase production was $4.556 \mathrm{mMol}$. The growth and lipase production was fairly constant at oil concentrations of $5 \mathrm{ml} / \mathrm{L}$ through $15 \mathrm{ml} / \mathrm{L}$. There was an increase in the growth (OD $0.245)$ and lipase production $(5.622 \mathrm{mMol})$ at $20 \mathrm{ml} / \mathrm{L}$ oil concentration. The organism had the highest growth (OD 0.298) and lipase production $(6.667 \mathrm{mMol}) \quad$ with oil concentration of $2.5 \mathrm{ml} / \mathrm{L}$.

\section{Effect of Temperature on the Growth}

Figure 4 shows the growth of Lysinibacillus sphaericus strain ODE16_EKITI at different temperatures through three different times. The highest growth of the isolate (with OD 2.81) was recorded at $30^{\circ} \mathrm{C}$ after $24 \mathrm{~h}$ while the least growth was recorded at $50^{\circ} \mathrm{C}$ with OD 0.022 after $12 \mathrm{~h}$ of incubation and OD 0.044 after $24 \mathrm{~h}$ of incubation. At $20^{\circ} \mathrm{C}$, the organism showed a substantial growth after $12 \mathrm{~h}$.

\section{Effects of Metals and Heavy Metals on the Growth and Lipase Production}

Varying growths were recorded for $L$. sphaericus strain ODE16_EKITI in the presence of metals and heavy metal as shown in Figure 5.

The organism showed the highest growth (with OD 0.301) and lipase production of $6.67 \mathrm{mMol}$ in the presence of magnesium $(\mathrm{Mg})$. In contrast, the least growth of the organism (with OD 0.045) and lipase production of $1.033 \mathrm{mMol}$ were recorded in 
the presence of iron. There were appreciable growth and lipase production by the isolate in the presence of sodium $(\mathrm{Na})$ and potassium (K).

In a bid to remediate the menace caused by the presence of lipids in many biological wastewater treatment systems, various researchers have focused on a way to explore lipase production by different microorganisms (Prasad and Manjunath, 2010; Trichel et al., 2010; Odeyemi et al., 2011; Facchin et al., 2013; Odeyemi et al., 2013a; 2013b; Odeyemi et al., 2014). The ability of Lysinibacillus sphaericus strain ODE16_EKITI to produce lipase has been reported by Odeyemi et al., (2014), but it has to be stressed that lipases with different characteristics became so prominent in recent times. The bioremediation capability of the organism on various components of the domestic oil-rich wastewater is hence further investigated.

From the inorganic components analysed, it was revealed that metals such as $\mathrm{Mg}, \mathrm{K}, \mathrm{Na}$, $\mathrm{Ca}$ and heavy metals such as Fe were found in high amount $(31.6 \mathrm{mg} / \mathrm{L})$. Manganese, Zinc and Copper were present in minimal amounts, which goes in line with Ghorbani et al., (2002) who reported that heavy metals such as $\mathrm{Zn}, \mathrm{Cu}$ and $\mathrm{Pb}$ are mainly present in industrial wastes and if present, can reduce the amount of microorganisms, especially at high concentrations. Magnesium and copper exhibited the highest and least concentrations respectively. This observation is in agreement with that of Malik and Jaiswal (2004) who reported that magnesium, potassium, sodium, iron and calcium are found in high concentrations in the wastewater because they are not usually bioavailable for microorganisms when present in low amounts. As expected, Lead and Nickel were not detected in the oil-rich wastewater since they are not biologically redox reactive and thus not usable for microbial respiration (Berg et al., 2001).

Lysinibacillus sphaericus strain ODE16_EKITI in this work, bioaccumulated high amounts of some of the inorganic content of oil-rich wastewater; indicating that the organism needed them for their metabolic process. Little amount of iron was accumulated, which may be because the organism only needs little amount of the heavy metal for its biological processes. Roane (2001) explained that the ability of some organisms to thrive in the wastewater may be attributed to their accumulation capability and therefore necessary for enzymatic functions and bacterial growth. An uptake mechanism exists that allows for the entrance of the metal ions into the cell (Nies, 1999). Considerable amount of phosphate was accumulated by the organism, showing that the organism had the ability to bio-remediate some active ingredients. The organism showed no accumulation ability whatsoever for sulphates, which may be because sulphate had an inhibitory effect on the growth of the microorganism (Surjawidjaja et al., 2004).

Lipase production was shown to be affected by incubation period, as it was recorded that the growth of the organism progressively reduced after the fourth day and the enzyme production also reduced after the fifth day of incubation. The maximum lipase activity (5.111mMol) was observed after 5 days' incubation. The organism grew in the medium at the rate of $0.292 \mathrm{mg} /$ day while it produced the lipase enzyme at the rate of $0.78 \mathrm{mM} / \mathrm{min}$ every day. This agrees with the work of Chipasa and Medrzycka (2007) in which the highest growth was observed on the fifth day and the oil content reduced due to the production of increasing level of lipase enzyme with maximal enzyme production was recorded on the fifth day. 
Lipases are generally produced in the presence of lipid such as oil or any other inducer, such as triacylglycerols, fatty acids, hydrolysable esters, bile salts and glycerol (Sharma et al., 2009). Lipidic carbon sources serve as inducers, vegetable oils have high contents of oleic and palmitic acid and has been reported as a good inducer for lipase production by many bacterial and fungal strains (Wang et al., 2008; Odeyemi et al., 2014).

Table.1 Inorganic components of domestic oil-rich wastewater sample

\begin{tabular}{llc}
\hline \multicolumn{1}{c}{ Mineral } & \multicolumn{1}{c}{ Element } & $\begin{array}{c}\text { Concentration } \\
\text { (mg/L) }\end{array}$ \\
\hline Metals & Calcium $(\mathrm{Ca})$ & 13.4 \\
& Magnesium $(\mathrm{Mg})$ & 54.4 \\
& Potassium $(\mathrm{K})$ & 43.2 \\
& Sodium $(\mathrm{Na})$ & 39.2 \\
\hline Heavy metals & Copper $(\mathrm{Cu})$ & \\
& Iron $(\mathrm{Fe})$ & 0.08 \\
& Lead $(\mathrm{Pb})$ & 31.6 \\
& Manganese $(\mathrm{Mn})$ & 0.40 \\
& Nickel $(\mathrm{Ni})$ & $\mathrm{ND}$ \\
& Zinc $(\mathrm{Zn})$ & 0.61 \\
\hline Active ingredients & & \\
& Phosphate $\left(\mathrm{PO}_{4}\right)$ & 6.41 \\
& Silica & 1.65 \\
& Soda ash & 0.82 \\
& Sulphate $\left(\mathrm{SO}_{4}\right)$ & 4.67 \\
& Surfactant & 0.02 \\
\hline
\end{tabular}

Fig.1 Percentage accumulation of inorganic components of oil-rich wastewater by Lysinibacillus sphaericus strain ODE16_EKITI

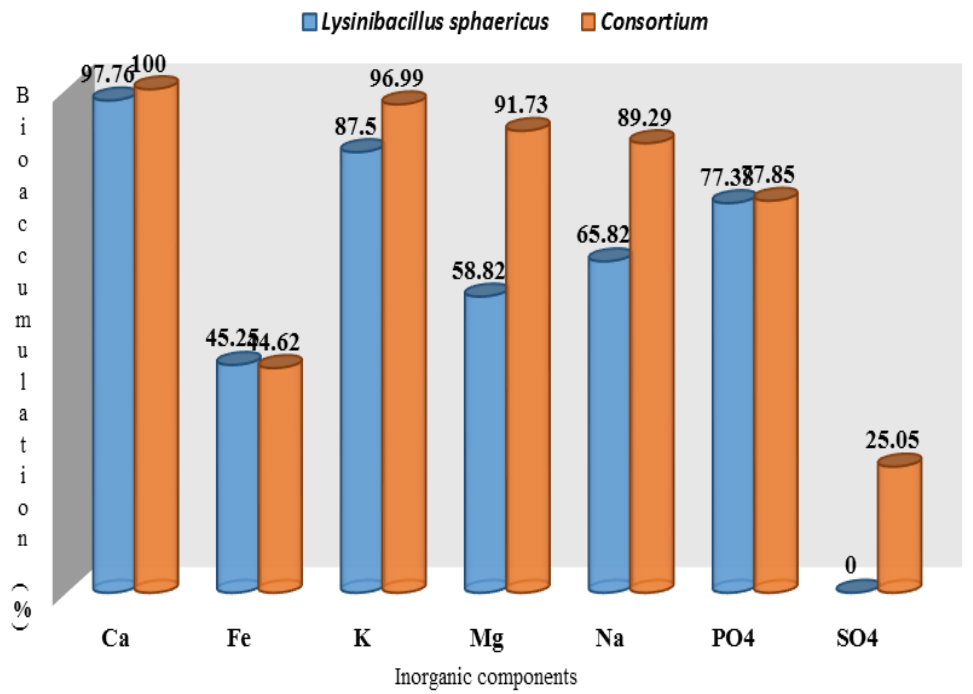


Fig.2 Growth and lipase production by L. sphaericus strain ODE16_EKITI at different incubation times

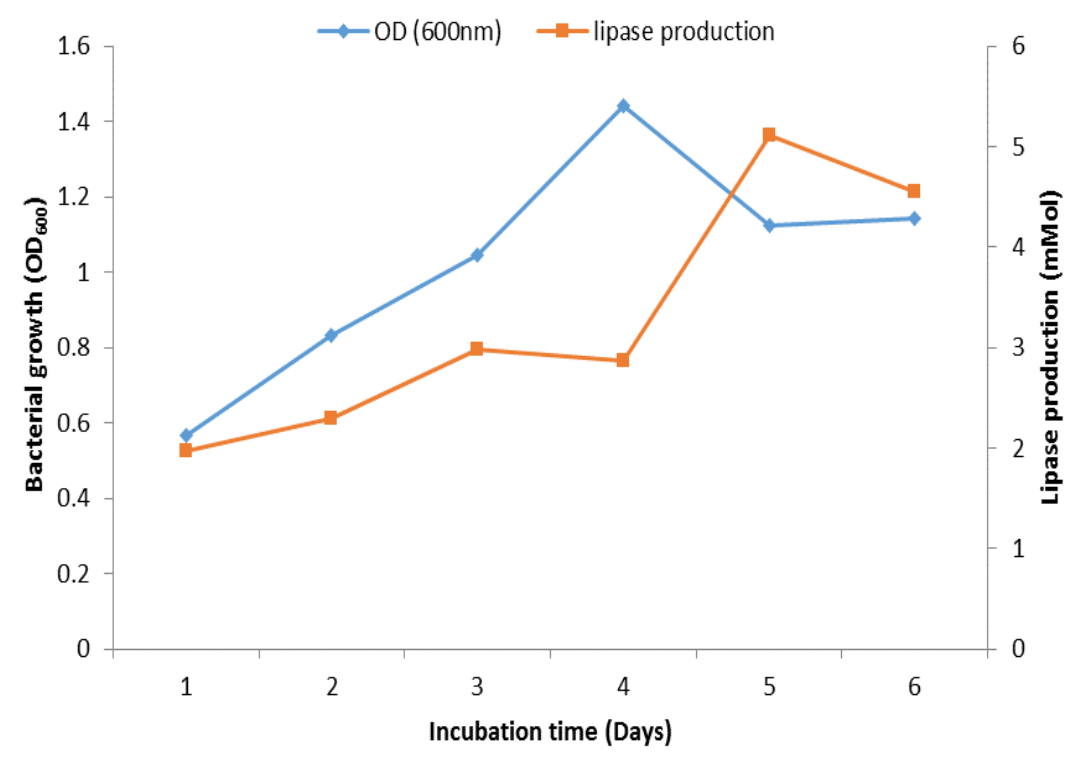

Fig.3 Growth and lipase production by L. sphaericus strain ODE16_EKITI at different oil concentrations

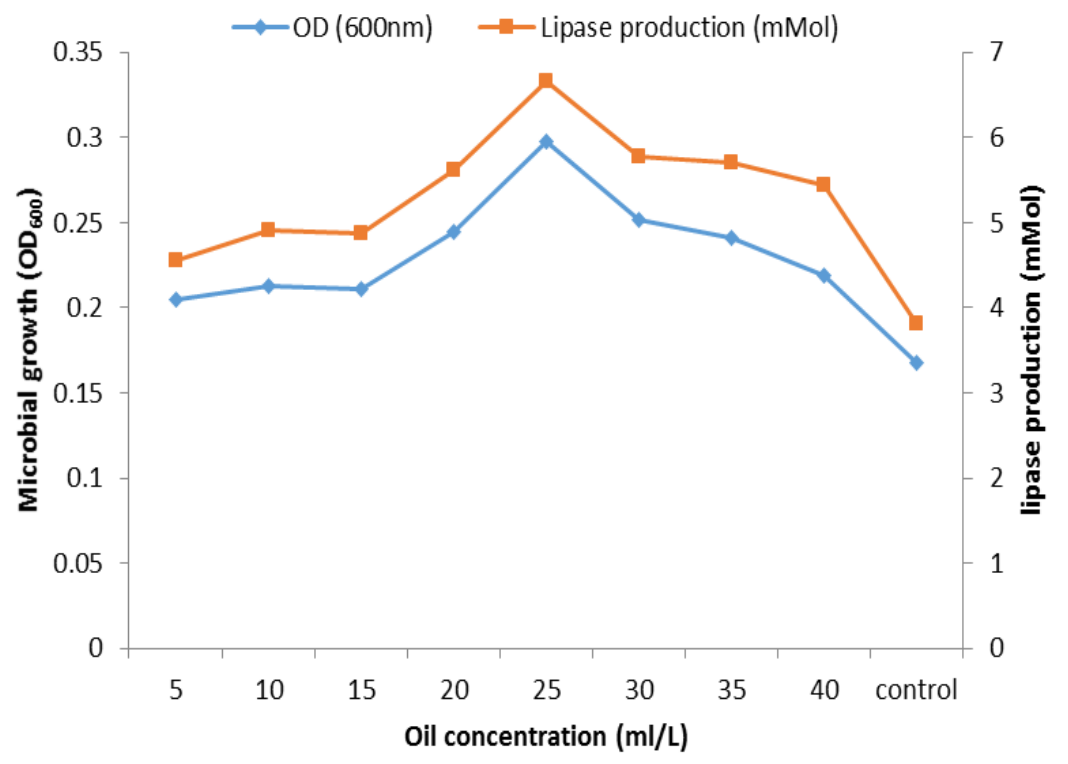


Fig.4 Growth of Lysinibacillus sphaericus strain ODE16_EKITI at different temperatures

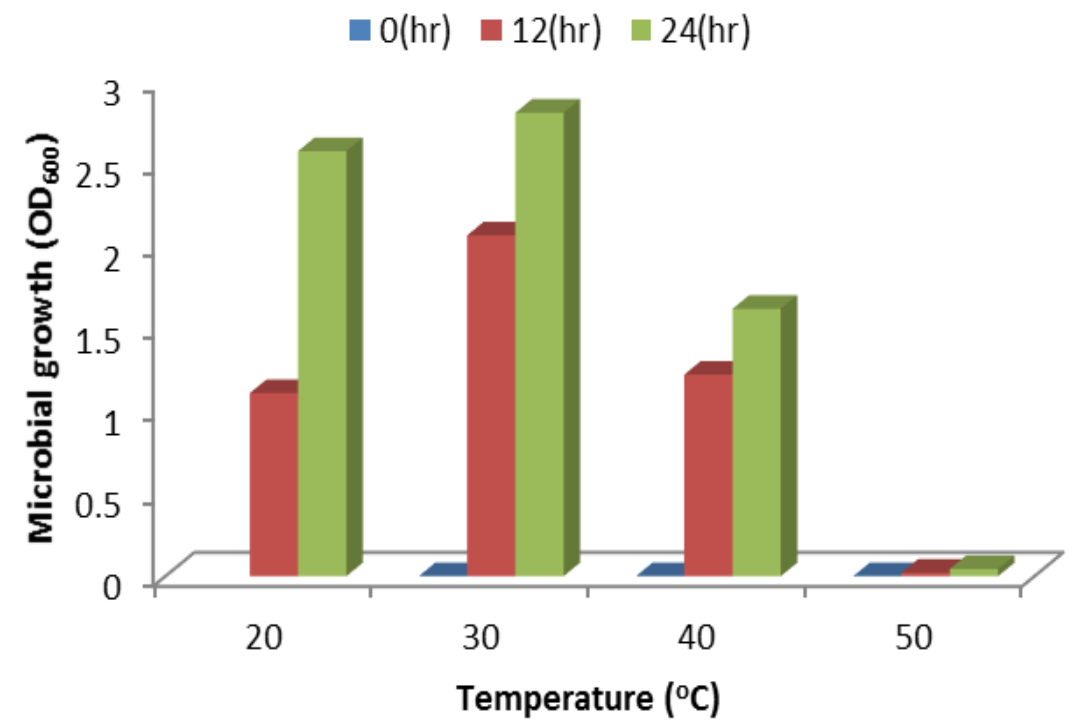

Fig.5 Growth and lipase production by L. sphaericus strain ODE16_EKITI in the presence of different metals

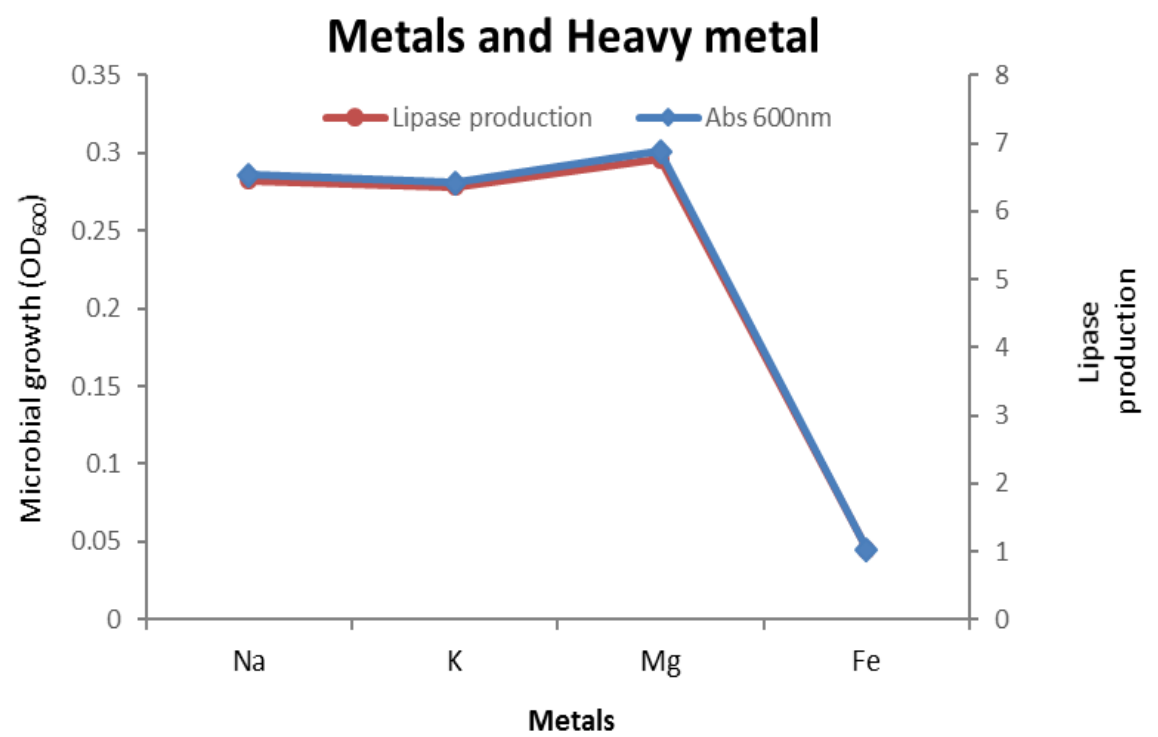

During this study, maximum lipase activity was achieved in the presence of $25 \mathrm{ml} / \mathrm{L}$, which is in consonance with the observation of Misbah and Haq (2014) who indicated that $20 \mathrm{ml} / \mathrm{L}$ olive oil served as an inducer with the substrate. An additional amount of lipid was more effective in enhancing lipase production than any other carbon source.
It was observed that further increase in oil concentration did not favour lipase production in this work, which might be due to poor oxygen transfer as explained by PereiraMeirelles et al., (2005). Furthermore, they explained that at a constant air flow rate $(\mathrm{Q}=$ $\left.1 \mathrm{dm}^{3} / \mathrm{min}, 0.8 \mathrm{vvm}\right)$, lipase production was higher at a high stirring speed between 
$200 \mathrm{rpm}$ to $400 \mathrm{rpm}$ when most of the lipid was consumed while at lower stirring speed of 100rpm no significant lipid consumption was observed in $24 \mathrm{~h}$. The maximum production of lipase at low oil concentration may be due to availability of oxygen for the organism to thrive in the basal medium; this is in agreement with the work of Odeyemi et al., (2011) who also reported that oxygen became much available as an electron acceptor, because Lysinibacillus sphaericus strain ODE16_EKITI thrived well wherever oxygen was available.

The optimum temperature for lipase production was observed to be $30^{\circ} \mathrm{C}$, concurring with the work of Bhatti et al., (2007) that reported inhibition of microbial growth and enzyme production due to high temperature. An increase in temperature, increases the number of effective collision between the enzyme and substrate to form activated complex and thus the rate of reaction increased. There is limit to increase in the enzyme activity when there is an increase in temperature (Bayoumi et al., 2007). Murray et al., (2003) also related in his work, that when the rate of enzymatic reactions is measured at several temperatures, there was an optimal temperature at which the reaction was most rapid, but when it was above that temperature, the reaction rate decreased sharply mainly due to the denaturation of enzymes by heat. Meanwhile, increase in temperature may also influence the secretion of extracellular enzymes as stated by Pirt (1975) that the temperature influenced the secretion of extracellular enzymes by changing the physical properties of the cell membrane. Going by the work by Palma et al., (2000) which reported that increased production of protease at higher temperatures will lead to deactivation of lipase, the reduction in lipase activity at higher temperature in this study may be due to the deactivation of lipase with increased production of proteases.
Lysinibacillus sphaericus strain ODE16_EKITI lipases showed hydrolytic ability against $\mathrm{K}^{+}, \mathrm{Na}^{+}$and $\mathrm{Mg}^{2+}$ three times higher than against $\mathrm{Fe}^{3+}$. Interestingly, $\mathrm{Mg}^{2+}$ ions resulted in a maximal increase in lipase activity. This is in agreement with the work of Sharma et al., (2001; 2009) who reported that lipase activity was enhanced in the presence of $\mathrm{K}^{+}$and $\mathrm{Ca}^{2+}$ and $\mathrm{Mg}^{2+}$ ions, but inhibited by $\mathrm{Fe}^{2+}$ and $\mathrm{Hg}^{2+}$ ions. Also Annamalai et al., (2011) in their work found that some metal ions, $\mathrm{Ni}^{2+}, \mathrm{Mn}^{2+}, \mathrm{Hg}^{2+}, \mathrm{Fe}^{2+}$ and $\mathrm{Fe}^{3+}$ slightly inhibited enzyme activity and no effect was found with $\mathrm{Cu}^{2+}$. The activity of lipases may be inhibited or stimulated by cofactors. More so, divalent cations such as calcium and magnesium often stimulate enzyme activity due to the formation of calcium salts with long chain fatty acids (Macrae and Hammond, 1985).

In conclusion, as the global need of biodegrading enzymes become alarming, so also the search for a new, highly efficient lipase with different characteristics is rapidly growing and apparently difficult. The present work has offered us the opportunity to investigate a lipolytic bacterium, Lysinibacillus sphaericus strain ODE16_EKITI that can produce lipase ranging between $5.1 \mathrm{mMol}$ to $6.0 \mathrm{mMol}$ at $30^{\circ} \mathrm{C}$ and $2.5 \%$ palm oil concentration after the 5th day and this could be enhanced with magnesium ion $\left(\mathrm{Mg}^{2+}\right)$. This enzyme also showed potentials of bioaccumulation of some heavy metals. L. sphaericus strain ODE16_EKITI is thereby presented as a promising tool for biotechnological exploitation in remediation of wastewater.

\section{References}

Amin, M. and Bhatti, H.N. 2014. Effect of physicochemical parameters on lipase production by Penicillium fellutanum using canola seed oil cake as substrate. 
Int. J. Agri. Biol., 16: 118-124.

Annamalai, N., Elayaraja, S., Vijayalakshmi, S., Balasubramanian, T. 2011. Thermostable alkaline tolerant lipase from Bacillus licheniformis using peanut oil cake as a substrate. African $J$. Biochem. Res., 5: 176-181.

AOAC. 1990. Official Methods of Analysis. Association of Official Analytical Chemists, Washington, D. C. 15th Edn.

AOAC. 2006. Official Methods of Analysis.18th Ed Association of Official Analytical Chemists International, Gaithersburg, MD, USA, Official Method, 920.39(A).

APHA. 1998. Standard method for the examination of Water and wastewaters. American Public Health Association 20th ed., New York.

Bayoumi, R., El-louboudey, S.S., Sidkey, N. M. and Abd-El-Rahman, M.A. 2007. Production, purification and characterization of thermoalkalophilic lipase for application in bio-detergent industry. J. Appl. Sci. Res., 3(12): 17521765.

Berg, M., Tran, C. H., Nguyen, T. C., Pham, H. V, Schertenleib, R. and Giger, W. 2001. Arsenic contamination of groundwater and drinking water in Vietnam; a human health drinking threat. Environ. Sci. Technol., 35(13): 2621-2626.

Bhatti, H. N., Rashid, M. H., Nawaz, R., Asgher, M., Perveen, R. and Jabbar, A. 2007. Optimization of media for enhanced glucoamylase production in solid-state fermentation by Fusarium solani. Food Technol. Biotechnol., 45: 51-56.

Bora, L. and Kalita, M. C. 2007. Production and optimization of thermostable lipase from a thermophilic Bacillus sp. LBN4. The Internet J. Microbiol., 4(1): http://www.ispub.com/journal/theinternet-journal-of- microbiology/volume-4-number$1 /$ production-and-optimizationofthermostable-lipase-from-athermophilic-bacillussp-lbn4.html\#sthash.qRHstqSc.dpbs

Chipasa, K.B. and Medrzycka, K. 2007. Characterization of the fate of lipids in activated sludge. J. Environ. Sci., 20: 536-542.

Cho, A.R., Yoo, S. K. and Kim, E. J. 2000. Cloning, sequencing and expression in Escherichia coli of a thermophilic lipase from Bacillus thermoleovorans ID-1. FEMS Microbiol. Lett., 186: 235 238.

Coronado, F. F., Esguerra, R. L., Sikat, G. M., Unciano, N. M., Peren, T. M. and Beraye, J. E. 2015. Isolation of Beneficial Microbes for the Biodegradation of Animal and Plant Oil in Fast Foods Wastewater Effluents. Int. Res. J. Biol. Sci., 4(9): 10-16.

Dharmsthiti, S. and Luchai, S. 1999. Production, purification and characterization of thermophilic lipase from Bacillus sp. THL027. FEMS Microbiol. $\quad$ Lett., 179: 241-246.

Facchin, S., Alves, P. D. D., Siqueira, S., Barroca, M. T., Victoria, J. M. N. and Kalapothakis, E. 2013. biodiversity and secretion of enzymes with potential utility in wastewater treatment. Open $J$. Ecol., 3(1): 34-47.

Ghorbani, N. R., Salehrastin, N. and Moeini A. 2002. Heavy metals affect the microbial populations and their activities. Symposium, 54: 2234-2241.

Gupta, R., Gupta, N. and Rathi, P. 2004. Bacterial lipases: An overview of production, purification and biochemical properties. Applied Microbiol. Biotechnol., 64: 763-781.

Hughes, K. L. and Christy, A. D. 2003. Bioreactor landfills: In Encyclopedia of agricultural, food, and biological 
engineering. Marcel Dekker, New York; pp. 104-107.

Kambovrova, M., Kirilova, N., Mandeva, R. and Derekova, A. 2003. Properties of thermostable lipase from a thermophilic Bacillus stearothermophilus MC7. J. Mol. Catalysis B. Enzymatic, 22: 307313.

Lotrakul, P. and Dharmsthiti, S. 1997. Purification and characterization of lipase from Aeromonas sobria LP004. J. Biotechnol., 54(2):113-120.

Macrae, A. R. and Hammond, R. C. 1985. Present and future application of lipases. Biotechnol. Genetic Engi. Rev., 3: 193-219.

Maire, R.M., Pepper, I. L. and Gerba, C. P. 2003. Important constituent in wastewater. J. Environ. Microbiol., 3: 149-173.

Malik, A. and Jaiswal, R. 2004. Lead accumulation by some resistant bacterial strains isolated from soil treated with industrial wastewater. World J. Microbiol. Biotechnol., 16: 111-122.

Mukesh Kumar, D. J., Rejitha, R., Devika, S., Balakumaran, M. D., Immaculate, N. R. A. and Kalaichelvan, P. T. 2012. Production, optimization and purification of lipase from Bacillus sp. MPTK 912 isolated from oil mill effluent. Adv. Appl. Sci. Res., 3(2): 930-938.

Murray, R. K., Granner, D. K., Mayes, P. A. and Rodwell, P. W. 2003. Harper's Illustrate Biochemistry, 26th edition. Published by Lange Medical (McGraw Hill). California.

Nies, D.H. 1999. Microbial heavy metal resistance. Appl. Microbiol. Biotechnol., 51: 730-750.

Odeyemi, A. T., Adebayo, A. A., Omoboye, O. O. and Ajayi, S. S. 2013b. Incidence of lipolytic mycoflora in domestic wastewater. J. Natural Sci. Res.,
3(8): 150-155.

Odeyemi, A. T., Aderiye, B. I. and Bamidele, O. S. 2013a. Lipolytic activity of some strains of Klebsiella, Pseudomonas and Staphylococcus spp. from restaurant wastewater and receiving stream. $J$. Microbiol. Res., 3(1): 43-52.

Odeyemi, A. T., Aderiye, B. I., Adeyeye, E. I., Donbraye, E. and Faleye, T. 2014. Lipolytic activity and molecular identification of Pseudomonas aeruginosa and Lysinibacillus sphaericus isolated from domestic oil rich wastewater. British Microbiol. Res. J., 4(4): 392-404.

Odeyemi, A., Aderiye, J., Adeyeye, E. 2011. Changes in the microflora and chemical components of domestic oil rich wastewater. J. Microbiol. Biotechnol. Food Sci., 1(1): 126-147.

Pallavi, P., Chandra, S. J., Reddy, V. K. and Reddy, S. R. 2014. Optimization of cultural parameters for lipase production by Bacillus subtilis Y-IVI. Int. J. Curr. Microbiol. Appl. Sci., 3(12): 194-200.

Palma, M. B., Pinto, A. L., Gombert, A. K., Seitz, K. H., Kivatinitz, S. C., Castilho, L. R. and Freire, D. M. G. 2000. Lipase production by Penicillium restrictum using waste of industrial babasu oil production as substrate. Appl. Biochem. Biotechnol., 84-86: 1137-1145.

Pereira-Meirelles, F. V., Alonso, F. O. M., Oliveira, E. B. L. and Dellamora-Ortiz, G. M. 2005. Improvement of lipase production at different stirring speeds and oxygen levels. Brazilian J. Chem. Engi., 22(1): 9-18.

Pirt, S. J. 1975. Principles of cell cultivation. London: Blackwells Scientific Publications

Prasad, M.P. and Manjunath, K. 2011. Comparative study on biodegradation of lipid-rich wastewater using lipase producing bacterial species. Indian $J$ 
Biotechnol., (10): 121-124.

Reddy, S. R., Pallavi, P. 2012. Microbial lipases-An overview: In: Microbial diversity: Exploration and bioprospecting, Ram, S., Reddy, M. A., Singara, C. and Girisham, S. Eds.), Scientific Publishers (India), Jodhpur. Pp. 126-153.

Roane, T. M. 2001. Microbial remediation of metals. In Bioremediation: Principles and Application (Crawford, R. L. eds) Cambridge, U.K: Cambridge University Press, Pp. 312-340.

Sharma, A. and Mulimani, V. H. 2001. $\alpha-$ Galactosidase production by Aspergillus oryzae in solid-state fermentation. Bioresources Technol., 98: 958-961.

Sharma, A., Bardhan, D. and Patel, R. 2009. Optimization of physical parameters for lipase production from Arthrobacter sp. BGCC\#490. Indian J. Biochem. Biophysics, 46: 178-183

Shukia, B. N. and Desai, P. V. 2016. Isolation, characterization and optimization of lipase producing Pseudomonas spp. from oil contaminated sites. Int. J. Curr. Microbiol. Appl. Sci., 5(5): 902-909
Sulaimon, A. M., Odeyemi, A. T., Ogunjobi, A. A. and Ibrahim, I. O. 2014 Bioaccumulation of heavy metals using selected heavy metal tolerant organisms isolated from dumpsite leachate. Nature and Sci., 12(10):101-106.

Surjawidjaja, J. E., Hidayat, A. and Lesmana, M. 2004. Growth inhibition of enteric pathogens by zinc sulfate: An in vitro study. Med. Principles and Practice, 13: 286-289.

Trichel, H., Oliveira, D., Mazutti, M. A., Luccio, M. D., Oliveira, J. V. 2010. A review on microbial lipases production. Food and Bioprocess Technol., 3: 182196.

UNEP and UN-Habitat. 2010. Sick Water? The central role of wastewater management in sustainable development. Available at: http://www.grida.no/publications/rr/sick water/ accessed October 2014.

Wang, D., Xu, Y. and Shan, T. 2008. Effects of oils and oil-related substrates on the synthetic activity of membrane-bound lipase from Rhizopus chinensis and optimization of the lipase fermentation media. Biochem. Engi. J., 41: 30-37.

\section{How to cite this article:}

Aderiye, B.I., A.A. Adebayo and Bello, Mustapha. 2017. Bioaccumulation of Heavy Metals and Optimization of Lipase Production by Lysinibacillus sphaericus Strain ODE16_EKITI Isolated from Domestic Oil-Rich Wastewater. Int.J.Curr.Microbiol.App.Sci. 6(8): 3790-3802. doi: http://dx.doi.org/10.20546/ijcmas.2017.608.458 